\title{
A Study of Apolipoprotein E (Apo E) Gene Polymorphisms in Chronic Spinal Cord Compression and their Relation with Cervical Spondylotic Myelopathy
}

\author{
*Eman A.E. Badr, *Manal A. Safan, **Mahmoud M Hadhoud \\ *Medical Biochemistry, **Orthopedic Surgery Departments, \\ Faculty of Medicine - Minoufiya University
}

\begin{abstract}
Object: Cervical spondylotic myelopathy is a common disease of multifactorial origin in which neural and vascular processes contribute to the final neurological damage. Apolipoprotein (Apo) $E$ is a multifunctional protein with central roles in lipid metabolism and neurobiology. The aim of present study is to determine the possible relationship of polymorphisms of apolipoprotein $E$ (Apo E) gene with occurrence of cervical spondylotic myelopathy (CSM) in spinal cord compression patients. Methods: The present study was carried out on 60 consecutive patients (34 men, 26 women), with spinal cord compression who underwent anterior microsurgical decompression. The studied subjects were classified into two groups: Group (I): It included 32 patients with chronic spinal cord compression without cervical spondylotic myelopathy (18 males and 14 females), Group (II): It included 28 patients with chronic spinal cord compression with cervical spondylotic myelopathy (16 males and 12 females). Neurological deficits were classified according to the modified Japanese Orthopedic Association Scale. All studied persons were subjected to full history taking, general clinical examination, MRI and laboratory investigations including ApoE genotyping which was carried out by isolation of DNA from venous blood samples. The APOE genotypes were determined by polymerase chain reaction followed by restriction enzyme digestion (PCR-RFLP) analysis followed by agarose gel electrophoresis of digested fragments. Results: The results of the present study showed a significant increase in group II when compared to group I as regarding the age $(P<0.05)$, duration of symptoms $(P<0.001)$, number of affected segment $s(P<0.001)$ and a significant decrease in the diameter of spinal canal $(P<0.001)$, whereas no significant difference regarding gender. On comparing the two studied groups a significant difference was found as regards apolipoprotein E genotype distribution with increased frequency of the E4 genotype in group II, the E4 allele was significantly increased in patients with CSM when compared with the other group without CSM, whereas no significant differences in the distribution of $E_{2}$ and $E_{3}$ alleles. The odds ratio for E4 allele was 3.2 (95\% CI: 1.3-9.8). Multiple regression analysis revealed that duration of symptoms, number of affected segments and diameter of spinal canal are independent risk factors for CSM. Conclusions: It could be concluded that E4 polymorphism of the ApoE gene is associated with the susceptibility to CSM in spinal cord compression and that, longer duration of symptoms, smaller diameter of spinal canal and more number of affected segments
\end{abstract}


are risk factors for such complication. The presence of the ApoE E4 allele is an independent predictor for presence of CSM. Further studies are needed to evaluate the type of ApoE polymorphism in patient with improvement or no improvement after surgery.

Key Words • cervical spondylotic myelopathy $\bullet$ apolipoprotein $E$ •apolipoprotein E polymorphism • spinal cord compression •

\section{INTRODUCTION}

Cervical spondylotic myelopathy $(\mathrm{CSM})$ is a well-known clinical syndrome of multifactorial origin and is the most common acquired cause of spinal cord disease ${ }^{(\mathbf{1})}$.

Risk factors believed to be most important for the development of CSM are canal stenosis beyond a critical size, extent of spinal cord compression, and dynamic mechanical factors such as axial tension during stretching over the anterior osteophytes ${ }^{(2)}$.

Although spinal canal stenosis with reduction of the anteroposterior diameter of the spinal cord has been proven to be a major risk factor of $\mathrm{CSM}^{(3)}$, recent studies suggest that not every patient with spinal canal stenosis or carriers of other risk factors develop CSM. Instead, only a small fraction of these patients will develop symptoms of $\mathrm{CSM}^{(4)}$.

Beyond the proven risk factors, genetic factors have been supposed to be responsible for the development of CSM. One of those genes which are associated with the development of neurologic diseases is the apolipoprotein E gene (Apo E) ${ }^{(5)}$.

Apolipoprotein $\mathrm{E}$ is a multifunctional protein with central roles in lipid metabolism and neurobiology. It has three common isoforms (apoE2, apoE3, and apoE4) with different effects on lipid and neuronal homeostasis ${ }^{(6,7)}$.

The Apo E gene, located on chromosome 19, is composed of three alleles (E2, E3 and E4) that give rise to six different genotypes (E2/2, E2/3, $\mathrm{E} 2 / 4, \mathrm{E} 3 / 3, \mathrm{E} 3 / 4$, and E4/4) .The three alleles differ in their frequencies: E4 (15-20\%), E3 (65-70\%), and E2 (5$10 \%)$. The E3 allele differs from the E2 allele by an amino acid substitution of arginine for cysteine at codon 158 , while the $\mathrm{E} 4$ differs from E3 by a substitution of arginine for cysteine at residue $112^{(\mathbf{8 , 9})}$.

Neuronal expression of ApoE has been controversial. It is produced by several types of cells in the central nervous system, including astrocytes ${ }^{(10)}$ and activated microglia ${ }^{(11)}$.

Neuron-derived apoE3 and apoE4 differ in their susceptibility to proteolysis and in their effects on mitochondrial function, tau phosphorylation, lysosomal leakage, neurodegeneration, androgen receptor deficiency, and cognitive decline ${ }^{(12,13)}$.

In apoE4, Arg-112 orients the side chain of Arg-61 into the aqueous environment where it can interact with Glu-255, resulting in interaction between the $\mathrm{N}$ - and C-terminal domains. In apoE3, Arg-61 is not available to interact with glutamic acid- $255^{(14)}$.

ApoE4 contributes to neuropathology by interacting with the amyloid pathway to modulate 
amyloid $\beta(\mathrm{A} \beta)$ peptide synthesis or clearance $^{(15)}$. Also, ApoE4 synthesized by neurons undergoes proteolytic cleavage to a much greater extent than apoE3. The resulting fragments with C-terminal truncations escape the secretory pathway and enter the cytosol. Most of these fragments are neurotoxic ${ }^{(12) .}$

Thus, the aim of the present study is to find Apo E gene expression role in spinal cord compression patients and the possible relationship of polymorphisms of apolipoprotein $\mathrm{E}$ (ApoE) gene with occurrence of cervical spondylotic myelopathy (CSM) in these patients.

\section{SUBJECTS \& METHODS}

Subjects: The present study was carried out on 60 subjects with chronic spinal cord compression with and without cervical spondylotic myelopathy (CSM). The patients were selected from the Orthopedics Surgery Clinics and Inpatients, Menoufiya University Hospitals in the period from Jan to July-2010. The study was approved by the ethics committee of our institute.

The subjects were divided into two groups:

Group (I): It included 32 patients with chronic spinal cord compression without cervical spondylotic myelopathy (18 males and 14 females). Their mean age was $36.06 \pm$ 7.76 years. The mean duration of chronic spinal cord compression was $10.78 \pm 3.60$ months.

Group (II): It included 28 patients with chronic spinal cord compression with cervical spondylotic myelopathy (16 males and 12 females). Their mean age was $42.89 \pm$ 8.70 years. The mean duration of chronic spinal cord compression was $20.14 \pm 2.95$ months.

Diagnosis of chronic spinal cord compression is based on neurological examination and magnetic resonance imaging (MRI).A modification of the Japanese Orthopedic Association Scale (mJOA) for functional assessment of cervical spondylotic myelopathy was used to evaluate functional status ${ }^{(16)}$. The scale assess motor dysfunction of the upper extremities (0-5 scores) and lower extremities (0-7 scores), as well as sensory dysfunction of the upper extremities ( $0-3$ scores), in addition to sphincter dysfunction (0-3 scores).

The maximum score is 18 which denote absence of any motor, sensory or sphincter dysfunction. However, we also considered additional minor clinical signs of cervical myelopathy. Patients were excluded if they had other central or peripheral neurological conditions or subjected to previous cervical spine surgery and/or trauma. Patients under the age of 18 years were also excluded.

All subjects were submitted to full history taking, general clinical examination. Clinical variables considered were age in years, number of affected segments, duration of symptoms in months, functional outcome (mJOA score). The diameter of the spinal canal was measured on MRI images and laboratory investigations including genotyping of the studied subjects for two polymorphisms of the apolipoprotein E gene using the PCR-RFLP (restriction fragment length 
polymorphism) technique was performed.

Sample Collection and assay: After 10 hours overnight fasting, six $\mathrm{ml}$ of venous blood were withdrawn from every fasting subject by sterile vein-puncture, and were transferred into EDTA containing tube and used for lymphocyte separation for further molecular analysis.

Lymphoflot solution (Ficol) was used in which lymphoflot has a higher density than that of platelets, lymphocytes or monocytcs, but a lower density than that of erythrocytes and granulocytes. Diluted blood with equal volume of saline is layered into the density gradient (Lymphoflot), during the centrifugation process, erythrocytes and granulocytes pass through the density gradient medium because of their higher density, whereas platelets, lymphocytes and monocytes settle above the density gradient on account of their lower density. The platelets were removed by means of two successive washing procedures with saline then lymphocytes were mixed with $1 \mathrm{ml}$ phosphate buffer solution and stored in cryotubes at $-80^{\circ} \mathrm{C}$ till analysis (Bio test AG, Dreieich, Germany). DNA from lymphocytes samples was isolated using the Qiagen extraction kit (Hilden, Germany), DNA eluted in buffer $\mathrm{AE}$ was stored at $-20{ }^{\circ} \mathrm{C}$ for further PCR procedure.
PCR for the apolipoprotein E gene polymorphism was done as follows, PCR was carried out to a total volume of $25 \mu \mathrm{l}$, containing $10 \mu \mathrm{l}$ of genomic DNA, $0.25 \mu \mathrm{l}$ of each primer $(50 \mu \mathrm{M})$ (Midland, Texas), 2.5 $\mu \mathrm{l}$ of $10 \mathrm{x}$ Taq polymerase buffer $(25$ $\mathrm{mM} \quad \mathrm{MgCl}_{2}$ ) (Qiagen Hilden, Germany), $0.25 \mu$ of AmpliTaq DNA polymerase (5units/ $\mu \mathrm{l}$ ) (QIAGEN Hilden, Germany), $0.5 \mu \mathrm{l}$ of dNTPs (10mM) (Qiagen Hilden, Germany), $3 \mathrm{ul}$ of DMSO and $8.25 \mu \mathrm{l}$ of $\mathrm{H}_{2} \mathrm{O}$.

The apolipoprotein E gene polymorphism was analyzed using the following primers ${ }^{(17) .}$

- Forward:

5'-TCCAAGGAGCTGCAGGCGGCGCA-3'

- Reverse:

5'-GCCCCGGCCTGGTACACTGCCA-3'.

PCR amplification for polymorphisms was performed in a programmable thermal cycler Perkin Elmer thermal cycler 2400 (USA). One cycle at $94^{\circ} \mathrm{C}$ for 5 minutes followed by 40 cycles at $94^{\circ} \mathrm{C}$ for 1 minute; $60^{\circ} \mathrm{C}$ for 1.5 minute; $72{ }^{\circ} \mathrm{C}$ for 1.5 minute; and one final cycle of extension at $72^{\circ} \mathrm{C}$ for 7 minutes.

The amplification products were separated by electrophoresis through $3 \%$ agarose gel stained with ethidium bromide. The length of the expected target is $218 \mathrm{bp}$. Ladder of $100 \mathrm{bp}$ was used. 


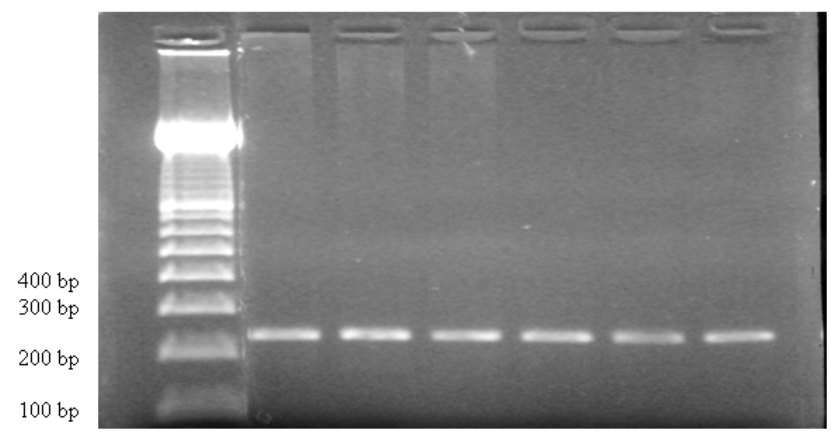

Fig.1. The length of the expected target is $218 \mathrm{bp}$. ladder of $100 \mathrm{bp}$ was used

The PCR products at $218 \mathrm{bp}$ for the apolipoprotein $\mathrm{E}$ gene polymorphism were mixed with 10 units of HaelI restriction enzyme (provided by Biolabs, New England) and 2.5 units of Afl III (provided by Biolabs, New England). The reaction conditions were, $6.25 \mu$ l nuclease-free water, $2.5 \mu$ 10XBuffer $3,15 \mu \mathrm{lPR}$ product, $2.5 \mu 1$ 100X BSA buffer, 0.5 ul (10 units) Hae II and $0.5 \mu \mathrm{l}$ (2.5units) Afl III. The reaction was incubated at $37^{\circ} \mathrm{C}$ over night then $25 \mu \mathrm{l}$ of the products was loaded into a $3 \%$ agarose gel containing ethidium bromide for electrophoresis and, the agarose gel was visualized under UV light ${ }^{(17)}$

Statistical analysis: Results were collected, tabulated, statistically analyzed by IBM personal computer and SPSS version 11. Chi-square test $\left(\chi^{2}\right)$ : was used to study association between two qualitative variables. Odds ratio describe the probability that people who are exposed to a certain factor will have a disease compared to people who are not exposed to the factor. Student unpaired t-test was used for comparison between two groups having quantitative variables. Multiple regression analysis calculates the effects of risk factors as independent Odds ratios with the effects of other confounders removed. P-value of $<0.05$ was considered statistically significant.

\section{RESULTS}

The results of the present study are presented in tables (1-5) and figures (1-3). 
Table (1): Clinical characteristics and radiological features of the two studied groups

\begin{tabular}{l|lll}
\hline & $\begin{array}{l}\text { Group I } \\
\text { No CSM (No=32) } \\
\text { Mean } \pm \text { SD }\end{array}$ & $\begin{array}{l}\text { Group II } \\
\text { CSM (No=28) } \\
\text { Mean } \pm \text { SD }\end{array}$ & \\
\hline Age (years) & $42.89 \pm 7.76$ & $49.06 \pm 8.70$ & $<0.05$ \\
Duration of symptoms (months) & $10.78 \pm 3.60$ & $20.14 \pm 2.95$ & $<0.001$ \\
Number of affected segments & $1.47 \pm 0.51$ & $2.89 \pm 0.83$ & $<0.001$ \\
Diameter of spinal canal (mm) & $12.12 \pm 1.68$ & $6.96 \pm 1.37$ & $<0.001$ \\
Male/Female: Number & $18 / 14$ & $16 / 12$ & $>0.05$ \\
\multicolumn{1}{c}{$\%$} & $56 / 44$ & $57 / 43$ & \\
\hline
\end{tabular}

This table shows significant increase in the mean of age in years $(\mathrm{P}<0.05)$, duration of symptoms in months and number of affected segments $(\mathrm{P}<0001)$ in patients with CSM when compared to non CSM and a significant decrease for the mean of the diameter of spinal canal in millimeter $(\mathrm{P}<0.001)$. However, there was shows no significant difference between patients with CSM and non CSM as regarding gender distribution $(\mathrm{P}>0.05)$.

Table (2): Distribution of the apolipoprotein E genotypes among the two studied groups

\begin{tabular}{|c|c|c|c|c|c|}
\hline & $\begin{array}{l}\text { Gro } \\
\text { No } \\
\text { No } \\
\end{array}$ & $\begin{array}{c}(\mathrm{No}=32) \\
\%\end{array}$ & $\begin{array}{l}\text { Gro } \\
\text { CSI } \\
\text { No } \\
\end{array}$ & $\begin{array}{r}=28) \\
\%\end{array}$ & $\mathbf{P}$ \\
\hline $\begin{array}{l}\text { Apo E genotypes: } \\
-\mathbf{E}_{3} / \mathbf{E}_{3} \\
-\mathbf{E}_{3} / \mathbf{E}_{2} \\
-\mathbf{E}_{3} / \mathbf{E}_{4} \\
-\mathbf{E}_{4} / \mathbf{E}_{4} \\
-\mathbf{E}_{2} / \mathbf{E}_{2}\end{array}$ & $\begin{array}{l}22 \\
5 \\
4 \\
0 \\
1\end{array}$ & $\begin{array}{r}68.8 \\
15.6 \\
12.5 \\
0.0 \\
3.1\end{array}$ & $\begin{array}{l}15 \\
4 \\
8 \\
1 \\
0\end{array}$ & $\begin{array}{r}53.6 \\
14.3 \\
28.6 \\
3.5 \\
0.0\end{array}$ & $<0.05$ \\
\hline
\end{tabular}

This table shows a significant difference as regarding Apo $\mathrm{E}$ genotypes distribution $(\mathrm{P}<0.05)$.

Table (3): Distribution of the apolipoprotein $E$ alleles among the two studied groups

\begin{tabular}{|l|lc|lc|l|}
\hline \multirow{2}{*}{ Apo E allele } & \multicolumn{2}{|l|}{ Group I } & \multicolumn{2}{|l|}{ Group II } & \multirow{2}{l|}{} \\
& No CSM (No=32) & \multicolumn{2}{l|}{ CSM (No=28) } & P \\
& No & \% & No & \% & \\
\hline E2 & 6 & 9.4 & 4 & 7.1 & $>0.05$ \\
\hline E3 & 53 & 82.8 & 42 & 75.0 & $>0.05$ \\
\hline E4 & 5 & 7.8 & 10 & 17.9 & $<0.05$ \\
\hline Total & 64 & 100 & 56 & 100 & \\
\hline
\end{tabular}

This table presents that the Apo E alleles only $\mathrm{E}_{4}$ shows a significant association with CSM $(\mathrm{P}<0.05)$, whereas no statistically significant differences in the distribution of $\mathrm{E}_{2}$ and $\mathrm{E}_{3}$ alleles between patients with CSM and non CSM (P>0.05). 
Table (4): Odds ratio and CI 95\% of risk factors of cervical spondylotic myelopathy

\begin{tabular}{l|ll}
\hline Risk factors & Odds ratio & CI 95\% \\
\hline Age & 0.9 & $0.3-2.3$ \\
Sex & 0.7 & $0.4-1.9$ \\
Duration of symptoms (months) & 1.2 & $0.5-1.4$ \\
Number of affected segments & 1.8 & $0.7-2.2$ \\
Diameter of spinal canal (mm) & 2.4 & $0.9-3.6$ \\
Apo $\mathbf{E}_{\mathbf{4}}$ hetero or homozygous & 3.2 & $1.3-9.8$ \\
\hline
\end{tabular}

This table shows that age and sex are not considered as risk factors for CSM, while the duration of symptoms in months, the number of affected segments, the diameter of spinal canal in millimeter and Apo $\mathrm{E}_{4}$ hetero or homozygous are considered as risk factors for CSM.

RFLP analysis for the ApoE polymorphism:

Simultaneous digestion of $218 \mathrm{bp}$ by Hae II and Afl III restriction enzymes analysis showing the genotypes of the Apo E polymorphism, separated on a $3 \%$ agarose gel. The fragments were $145 \mathrm{bp}$ band indicating the E3 genotype, the $168 \mathrm{bp}$ indicating the E2 genotype and 195bp bands indicating the E4 genotype (digestion products). The molecular marker is a $100 \mathrm{bp}$ ladder (figure 2).

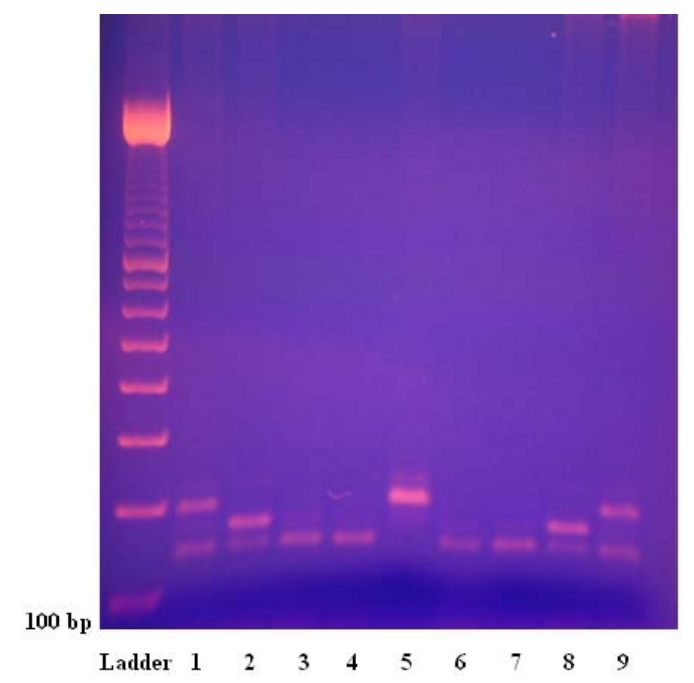

Fig. (2): lane1 shows E3/E4, lanes 2\&9 show E2/E3, lanes 3,4,6\&7 show E3/E3, lane $5 \mathrm{E} 4 / \mathrm{E} 4$, and lane 8 show E2/E3 genotypes respectively. 


\section{Surgical procedure:}

All patients underwent a single or multilevel anterior surgical decompression and fusion. The standard procedure was disscectomy with subsequent implantation of a cage and autogenous bone graft in 1 or more segments. 41 single level disscectomies and 19 multilevel disscectomies with cervical fusion were performed. Examples of the cases before and after operation are shown in figures 2 and 3.

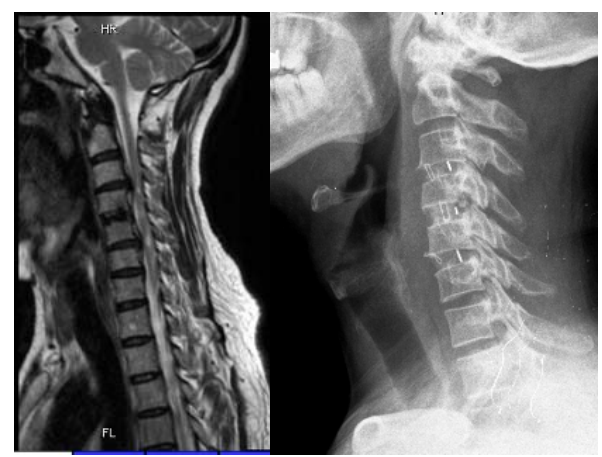

Figure (3): MRI and plain x-ray of a case of multiple level spinal cord compression with cervical spondylotic myelopathy and postoperative disscectomies and cervical fusion using cages.

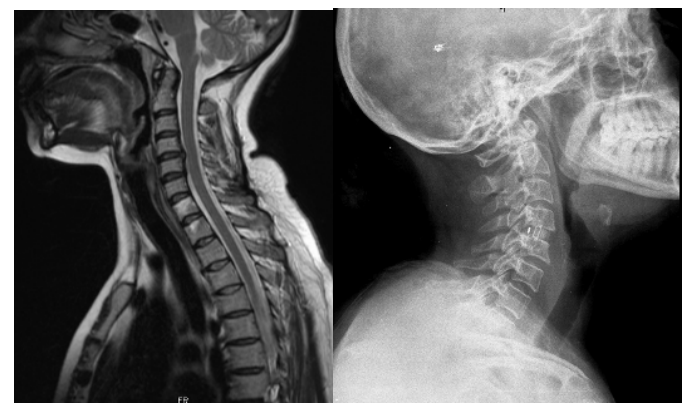

Figure (4): MRI and plain x-ray of a case of single level spinal cord compression without cervical spondylotic myelopathy and postoperative disscectomies and cervical fusion using cage.

\section{DISCUSSION}

Cervical spondylotic myelopathy (CSM) is a condition where the vascular and neural structures are compressed by bony spurring and soft tissue hypertrophy as well as intervertebral disc which causes ischemic damage to the spinal cord ${ }^{(18)}$.

Still the critical degree of spinal cord compression needed to induce pathologic changes is unknown. Moreover, it is difficult to infer the degree of dysfunction of the spinal 
cord from MRI findings alone ${ }^{(19)}$. Previous studies evaluating neurologic function and predictability of surgical results in cervical spondylotic myelopathy patients always depended on the morphologic changes of the cord and spinal structures ${ }^{(20)}$.

Several studies show that one of the genetic factors that may influence the occurrence and outcome in neurological diseases is $\mathrm{ApoE}$ polymorphism $^{(21,22,23)}$.

ApoE influences basic neurobiological processes, like axonal outgrowth, (24) axonal transport, (25) phosphorylation of the tau protein, ${ }^{(26)}$ regulation of dendritic spine morphology, ${ }^{(27)}$ cell survival to $\beta$ amyloid-induced toxicity, ${ }^{(28)}$ excitotoxic processes in neurodegeneration, ${ }^{(29)}$ microtubule polymerization, ${ }^{(\mathbf{3 0})}$ and potentiation of biological activity of ciliary neurotrophic factor ${ }^{(31)}$ in an isoform specific manner.

ApoE has two structural domains separated by a hinge region. The amino acid differences among the isoforms profoundly affect their structures and roles in disease ${ }^{(32,33)}$.

ApoE synthesis by neurons can be induced by various stressors or stimuli, possibly including age, oxidative stress, trauma, $\mathrm{A} \beta$ deposition, and ischemia. However, there is a marked difference in how apoE3 and apoE4 are handled by neurons ${ }^{(34)}$.

The aim of the current work is to determine the possible relationship of polymorphisms of apolipoprotein $\mathrm{E}$ gene in especially the isoform of E4 with cervical spondylotic myelopathy in spinal cord compression patients.
The present study showed that there was no significant difference in sex distribution among the two studied groups, while there was significant difference in age among the same groups. These results are in accordance with the study of Setzer et al., ${ }^{(5)}$ who found a significant differences between CSM and non CSM patients for the age distribution.

As regards to the risk factors for cervical spondylotic myelopathy, By applying multivariate regression analysis, this study revealed that duration of symptom (OR was 1.2, $95 \%$ CI 0.5 - 1.4), number of affected segments (OR 1.8, 95\% CI 0.7-2.2) and diameter of spinal canal (OR 2.4, 95\% CI 0.9 - 3.6) are independent risk factors of cervical spondylotic myelopathy. These results are matched with the study of Setzer et al. (5) who found a significant difference between CSM and non CSM patients for the diameter of the cervical spinal canal, for the duration of CSM and non-CSM symptoms, and for the number of affected segments.

A highly significant difference as regards apolipoprotein genotype distribution was found on comparing the two studied groups with increased frequency of the E4/E4 and E3/E4 genotype in group II. There was also increased frequency of the E4 allele in the cervical spondylotic myelopathy patients.

The current study revealed that the E4 allele of the apolipoprotein E polymorphism had significantly increased risk of cervical spondylotic myelopathy (OR 3.2; 95\% CI 1.3 9.8). This is matched with a recent hospital-based study of Setzer et al. ${ }^{(5)}$ who found that the ApoE genotype is 
associated with the development of CSM in patients with chronic cervical spinal cord compression in the way that patients with CSM are more frequently carriers of the ApoE allele E4 than those with cervical canal stenosis without CSM, and thus E4 might also be a risk factor for the development of CSM. Also, our results agree with those of Setzer et al. ${ }^{(35)}$ who showed that the carriers of ApoE E4 allele have a higher risk for non improvement after surgical decompression and stabilization.

The present study is in accordance also with the study of Seitz et al., 2003 ${ }^{(36)}$ and $2005^{(37)}$ who stated that ApoE is upregulated and is associated in chronic regenerative processes after spinal cord injury.

The present study agrees also with Leung et al. ${ }^{(\mathbf{3 8})}$ who stated that the E4 allele seems to a "susceptibility" factor which increases the risk of several neurologic diseases and worsens the prognosis in others.

However, there are also studies of Dunn et al., 2001 ${ }^{(39)}$ and Teasdale et al. $^{(40)}$ who could not demonstrate a clear association between ApoE gene polymorphism and the overall outcome in neurological diseases

The reason for that relationship is unclear, but it is thought that the E4 mutation might involved in chronic reactive/regenerative processes after neurological lesions ${ }^{(\mathbf{4 0})}$.

ApoE4 can cause neuropathology directly. ApoE4 also sets as the stage for "second hits" to precipitate neuropathology. These second hits may be genetic (as Parkinson's disease), metabolic (ischemia and oxidative stress), or environmental (aging, inflammation, and central nervous system trauma) ${ }^{(7)}$.

\section{CONCLUSION}

It can be concluded that E4 polymorphism of the ApoE gene is associated with the susceptibility to CSM in spinal cord compression and that, longer duration of symptoms, smaller diameter of spinal canal and more number of affected segments are risk factors for such complication. The presence of the ApoE E4 allele is an independent predictor for presence of CSM. However, the results of the current study are preliminary since the size of the cohort is rather small. Therefore, a larger cohort is needed to confirm the association of APOE gene polymorphism and occurrence of CSM in patients with spinal cord compression. Further studies are needed to evaluate the type of ApoE polymorphism in patients with improvement or no improvement after surgery.

\section{REFERENCES}

1. Fehlings MG, Skaf G (1998): A review of the pathophysiology of cervical spondylotic myelopathy with insights for potential novel mechanisms drawn from traumatic spinal cord injury. Spine 23:2730-2737.

2. Henderson FC, Geddes JF, Vaccaro AR, Woodard E, Berry KJ, Benzel EC (2005): Stretch-associated injury in cervical spondylotic myelopathy: new concept and review. Neurosurgery 56:1101-1113. 
3. Baptiste DC, Fehlings MG (2006): Pathophysiology of cervical myelopathy. Spine J., 6:190S-197S

4. Bednarik J, Kadanka Z, Dusek L, Kerkovsky M, Vohanka S, Novotny O (2008): Presymptomatic spondylotic cervical myelopathy: an updated predictive model. Eur. Spine J., 17:421-431.

5. Setzer M, Hermann E, Seifert V, Marquardt G (2008): Apolipoprotein E gene polymorphism and the risk of cervical myelopathy in patients with chronic spinal cord compression. Spine 33: 497-502.

6. Huang Y (2006): Molecular and cellular mechanisms of apolipoprotein E4 neurotoxicity and potential therapeutic strategies. Curr. Opin. Drug Discov. Devel., 9:627-641.

7. Mahley RW, Weisgraber KH, Huang Y (2006): Apolipoprotein E4: causative factor and therapeutic target in neuropathology, including Alzheimer's disease. Proc. Natl. Acad. Sci. USA 103:5644-5651.

8. Das HK, McPherson J, Bruns GA, Karathanasis SK, Breslow JL. (1985): Isolation, characterization, and mapping to chromosome 19 of the human apolipoprotein E gene. J. Biol. Chem., 260(10):6240-6247.

9. Kolovou G, Damaskos D, Anagnostopoulou K, Cokkinos DV. (2009): Apolipoprotein E gene polymorphism and gender. Ann. Clin. Lab. Sci., 39(2):120133.
10. Grehan S, Tse E, Taylor JM (2001): Two distal downstream enhancers direct expression of the human apolipoprotein E gene to astrocytes in the brain. J. Neurosci., 21:812-822.

11. Xu Q, Li Y, Cyras C, Sanan DA, Cordell B (2000): Isolation and characterization of apolipoproteins from murine microglia. Identification of a low density lipoprotein-like apolipoprotein J-rich but E-poor spherical particle. J. Biol. Chem., 275:31770 -31777.

12. Brecht WJ, Harris FM, Chang S, Tesseur I, Yu GQ, Xu Q, Fish JD, Wyss Coray T, Buttini M, Mucke L, Mahley RW, Huang Y (2004): Neuronspecific apolipoprotein E4 proteolysis is associated with increased tau phosphorylation in brains of transgenic mice. J. Neurosci., 24:2527-2534.

13. Chang S, Ma TR, Miranda RD, Balestra ME, Mahley RW, Huang Y (2005): Lipid- and receptor-binding regions of apolipoprotein E4 fragments act in concert to cause mitochondrial dysfunction and neurotoxicity. Proc. Natl. Acad. Sci. USA 102:18694-18699.

14. Zhong, N., and K. H. Weisgraber.

(2009):

Understanding the association of apolipoprotein E4 with Alzheimer's disease: clues from its structure. J. Biol. Chem., 284(10):6027-6031.

15. Ji, Z-S., K. Müllendorff, I. H. Cheng, R. D. Miranda, Y. Huang, and R. W. Mahley. (2006): Reactivity of 
apolipoprotein E4 and amyloid $\beta$ peptide: lysosomal stability and neurodegeneration. J. Biol. Chem., 281: 2683-2692.

16. Benzel, E.C., Lancon; J., Kesterson; L and Hadden; T (1991): Cervical laminectomy and dentate ligament section for cervical spondylotic myelopathy. J. Spinal Disord., 4:286-295.

17. Zivelin A, Rosenberg N, Peretz H, Amit Y, Kornbrot N, Seligsohn U. (1997): Improved method for genotyping Apolipoprotein E polymorphisms by a PCR-based assay simultaneously utilizing two distinct restriction enzymes. Clin. Chem., 43:1657-1659.

18. Lo YL, Chan LL, Lim W, Tan SB,Tan CT, Chen JL, FookChong S, Ratnagopal P. (2006): Transcranial magnetic stimulation screening for cord compression in cervical spondylosis. J. Neurol. Sci., 244:17-21.

19. Kanchiku T, Taguchi T, Kaneko K, et al. (2001): A correlation between magnetic resonance imaging and electrophysiological findings in cervical spondylotic myelopathy. Spine 13: 294-9.

20. Naderi S, Ozgen S, Necmettin $M$, et al. (1998): Cervical spondylotic myelopathy: surgical results and factors affecting prognosis. Neurosurgery 43: 4350.

21. Resnick DK, Schmitt C, Miranpuri GS, Dhodda VK, Isaacson $\mathbf{J}$, Vemuganti $\mathbf{R}$ (2004): Molecular evidence of repair and plasticity following spinal cord injury. Neuroreport 15:837-839.

22. Ruigrok YM, Slooter AJ, Bardoel A, Frijns CJ, Rinkel GJ, Wijmenga C (2005): Genes and outcome after aneurysmal subarachnoid hemorrhage. J. Neurol., 252:417-422.

23. Schmitt C, Miranpuri GS, Dhodda VK, Isaacson J, Vemuganti R, Resnick DK (2006): Changes in spinal cord injury-induced gene expression in rat are strain-dependent. Spine J., 6:113-119.

24. Nathan BP, Jiang Y, Wong GK, Shen F, Brewer GJ, Struble RG (2002): Apolipoprotein E4 inhibits, and apolipoprotein E3 promotes neurite outgrowth in cultured adult mouse cortical neurons through the low-density lipoprotein receptor-related protein. Brain Res., 928:96-105.

25. Tesseur I, Van Dorpe J, Bruynseels $\mathbf{K}$, Bronfman $\mathbf{F}$, Sciot R, Van Lommel A, et al. (2000) a: Prominent axonopathy and disruption of axonal transport in transgenic mice expressing human apolipoprotein E4 in neurons of brain and spinal cord. Am. J. Pathol., 157:1495-1510.

26. Tesseur I, Van Dorpe J, Spittaels K, Van den Haute C, Moechars D, Van Leuven $F$ (2000) b: Expression of human apolipoprotein E4 in neurons causes hyperphosphorylation of protein tau in the brains of transgenic mice. Am. J. Pathol., 156:951-964.

27. Ji Y, Gong Y, Gan W, Beach T, Holtzman DM, Wisniewski T (2003): Apolipoprotein E 
isoform-specific regulation of dendritic spine morphology in apolipoprotein E transgenic mice and Alzheimer's disease patients. Neuroscience 122:305-315.

28. Jordan J, Galindo MF, Miller RJ, Reardon CA, Getz GS, LaDu MJ (1998): Isoformspecific effect of apolipoprotein E on cell survival and betaamyloid-induced toxicity in rat hippocampal pyramidal neuronal cultures. J. Neurosci., 18:195204.

29. Buttini M, Orth M, Bellosta S, Akeefe H, Pitas RE, WyssCoray T, et al. (1999): Expression of human apolipoprotein E3 or E4 in the brains of apoE-/- mice: isoformspecific effects on neurodegeneration. J. Neurosci., 19:4867-4880.

30. Scott BL, Welch $K$, deSerrano V, Moss NC, Roses AD, Strittmatter WJ (1998): Human apolipoprotein E accelerates microtubule polymerization in vitro. Neurosci Lett 245:105-108.

31. Gutman CR, Strittmatter WJ, Weisgraber KH, Matthew WD (1997): Apolipoprotein E binds to and potentiates the biological activity of ciliary neurotrophic factor. J. Neurosci., 17:61146121.

32. Weisgraber, K. H. (1994): Apolipoprotein E: structurefunction relationships. Adv. Protein Chem., 45: 249-302.

33. Morrow, J. A., K. S. Arnold, J. Dong, M. E. Balestra, T. L. Innerarity, and $K$. $H$. Weisgraber. (2000): Effect of arginine 172 on the binding of apolipoprotein $\mathrm{E}$ to the low density lipoprotein receptor. J. Biol. Chem., 275: 2576-2580.

34. Xu, Q., A. Bernardo, D. Walker, T. Kanegawa, R. W. Mahley, and Y. Huang. (2006): Profile and regulation of apolipoprotein E (apoE) expression in the CNS in mice with targeting of green fluorescent protein gene to the apoE locus. J. Neurosci., 26: 4985-4994.

35. Setzer M., Frank D. Vrionis, Elvis J. Hermann, Volker Seifert, and Gerhard Marquardt, M.D. (2009): Effect of apolipoprotein $\mathrm{E}$ genotype on the outcome after anterior cervical decompression and fusion in patients with cervical spondylotic myelopathy J. Neurosurg. Spine 11:659-666.

36. Seitz A, Kragol M, Aglow E, Showe L, Heber-Katz E (2003): Apolipoprotein E expression after spinal cord injury in the mouse. J. Neurosci Res., 71:417-426.

37. Seitz A, Gourevitch D, Zhang XM, Clark L, Chen P, Kragol $M$, et al (2005): Sense and antisense transcripts of the apolipoprotein $\mathrm{E}$ gene in normal and ApoE knockout mice, their expression after spinal cord injury and corresponding human transcripts. Hum. Mol. Genet., 14:2661-2670.

38. Leung CH, Poon WS, Yu LM, et al. (2002): Apolipoprotein e genotype and outcome in aneurysmal subarachnoid hemorrhage. Stroke 33:548-52.

39. Dunn LT, Stewart E, Murray GD, Nicoll JA, Teasdale GM 
(2001): The influence of apolipoprotein E genotype on outcome after spontaneous subarachnoid hemorrhage: a preliminary study. Neurosurgery 48:1006-1010.
40. Teasdale GM, Murray GD, Nicoll JA (2005): The association between APOE epsilon4, age and outcome after head injury: a prospective cohort study. Brain 128:2556-2561.

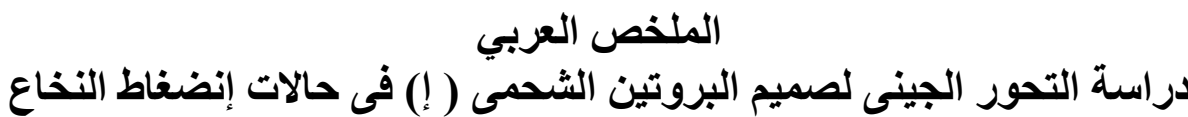

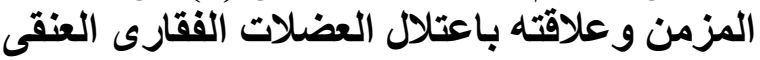 \\ ايمان عبل الفتاح بلر 'ـ منال عبد العزيز سعفان 'ـ محمود محد هد هود'

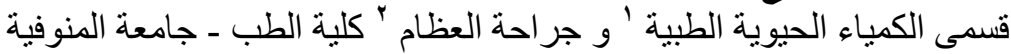

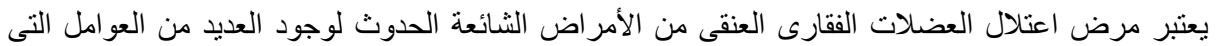

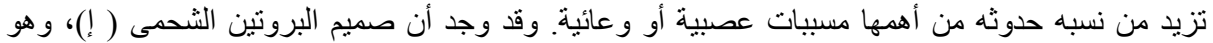

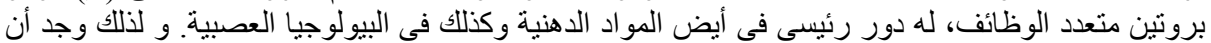

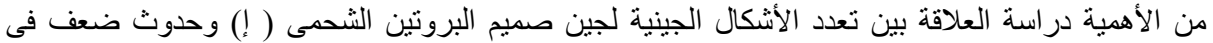

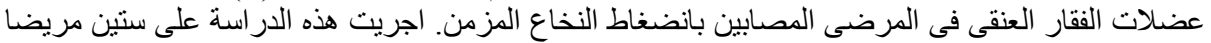

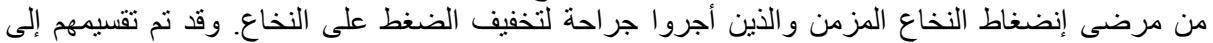

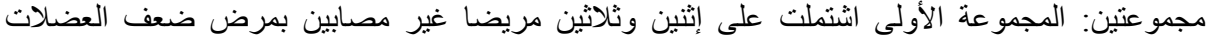

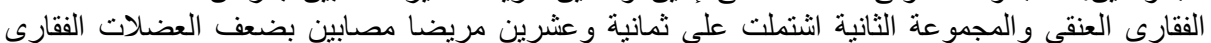

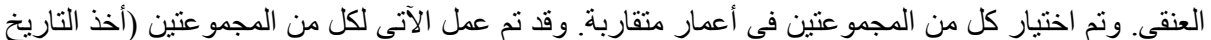

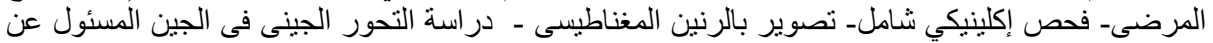

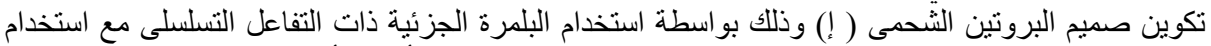

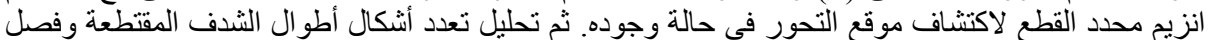

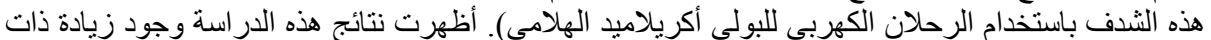

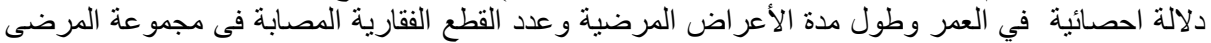

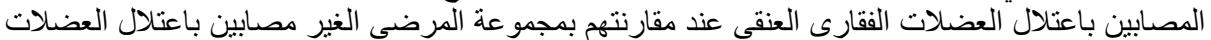

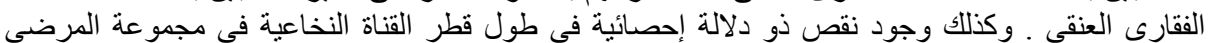

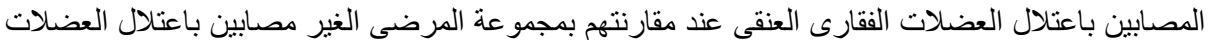

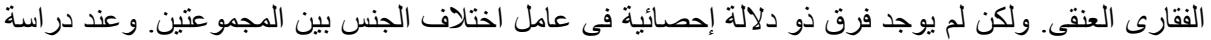

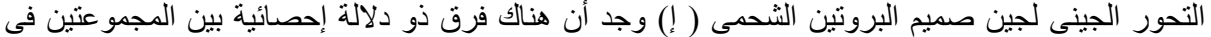

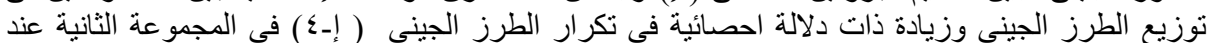

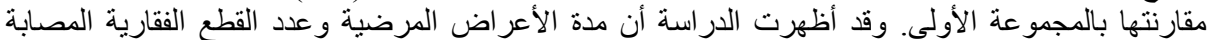

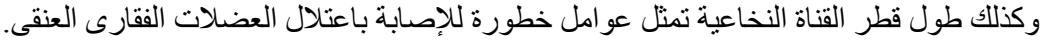

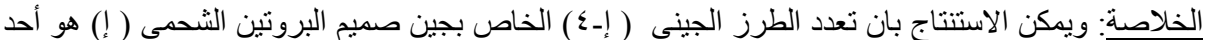

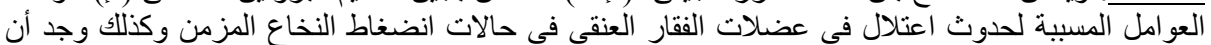

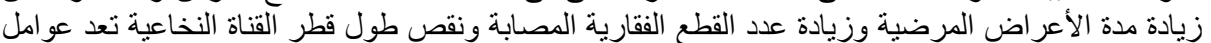
خطورة تزيد من فرص الإصابة بالمرض. 